\title{
Effect of tocopherol supplementation during last trimester of pregnancy on mRNA abundances of interleukins and angiogenesis in ovine placenta and uterus
}

Ramanathan K Kasimanickam, Vanmathy R Kasimanickam, Gary J Haldorson and Ahmed Tibary

\begin{abstract}
Background: Interleukins (IL) play an important role in angiogenesis. Tocopherol possesses immunomodulating effect in addition to antioxidant property. The objective of this study was to determine whether gamma tocopherol's (gT) angiogenic activity in placental network is enhanced via promoting interleukins.

Methods: Pregnant ewes ( $N=18)$ were supplemented, orally, with $500 \mathrm{mg}$ of alpha tocopherol $(\mathrm{aT} ; \mathrm{N}=6)$ or $1,000 \mathrm{mg}$ of $\mathrm{gT}(\mathrm{N}=7)$ or placebo (CON; $\mathrm{N}=5$ ) once daily from 107 to 137 days post breeding. Uterine and placental tissue samples were obtained at the end of supplementation to evaluate relative mRNA expressions of IL1b, IL-6, IL-8, Tumor Necrosis Factor (TNF) alpha, Vascular Endothelial Growth Factor (VEGF), kinase insert domain receptor (KDR; VGFR2; a type III receptor tyrosine kinase), and soluble fms-like tyrosine kniase-1 (sFlt1 or sVEGFR1) in uterus, caruncle and cotyledon.

Results: Oral supplementation of gT increased IL-6, IL-8, KDR and VEGF mRNA abundances whereas sFlt1 mRNA abundance was suppressed in uterus, caruncle and cotyledon, compared to aT and placebo treated ewes $(P<$ 0.05). The TNF alpha and IL-1b mRNA abundances were suppressed in uterus, caruncle and cotyledon but TNF alpha is higher in gT group compared to aT group $(P<0.05)$, whereas IL-1b was similar between treatment groups $(P>0.1)$.

Conclusions: Gamma tocopherol supplementation increased IL-6, IL-8, and KDR mRNA abundances and suppressed sFlt1 and TNFalpha mRNA abundances thereby increased VEGF mRNA expression and angiogenesis in placental vascular network during late gestation. It is plausible that the angiogenic effect of gamma tocopherol in placental vascular network is exerted via an alternate path by enhancing IL-6 and IL-8.
\end{abstract}

\section{Background}

Angiogenesis refers to the formation of new vascular beds, and is a critical process for normal placental growth and development [1-3]. Although numerous factors have been implicated in angiogenesis, recent observations have led to the identification of the major factors regulating the angiogenic process, including those that occur during placental vascularization. These angiogenic factors include the vascular endothelial growth factor (VEGF), fibroblast growth factor (FGF),

\footnotetext{
* Correspondence: ramkasi@vetmed.wsu.edu

College of Veterinary Medicine, Washington State University, Pullman, WA 99164, USA
}

and the angiopoietin (ANG) protein families, as well as their respective receptors [4-6]. The VEGF is the major angiogenic growth factor of the placenta because this protein probably accounts for most of the angiogenic activity produced by placental tissues [7-11]. The VEGF acts as specific mitogen for endothelial cells through specific membrane receptors, kinase domain-containing receptor (KDR), and the fin-like tyrosine kinase 1(Flt-1) [12]. When VEGF binds to its receptors, it initiates auto-phosphorylation, induces tyrosine kinase activity, and subsequently stimulates cellular responses in normal and abnormal angiogenesis. 
Several inflammatory interleukins have been linked with angiogenesis. These interleukins include IL-1, IL-6, and IL-8 [13-28]. Interleukin (IL)-8 acts as a potent chemoattractant for neutrophils, the major cellular component of acute inflammatory infiltrates [13,14]. In addition to this proinflammatory function, there is growing evidence that IL- 8 exerts effects on nonimmune cells, including the vascular endothelium [14]. The receptors for IL-8 are widely expressed on normal and various tumor cells and bind IL- 8 receptors with high affinity [15]. IL-8 expression correlates with vascularity and microvessel counts [16-18]. Similarly IL-6, a multifunctional cytokine and is a critical factor in various physiological conditions including immune regulation, hematopoiesis and inflammation by modulating a variety of events, such as cell proliferation, differentiation and apoptosis [19-21]. Studies have demonstrated that immunostaining for IL-6 was present in both syncytiotrophoblasts and extra-villous trophoblasts [22]. IL-6 stimulates VEGF synthesis and release, and promotes angiogenesis occurrence in vivo and in vitro [23-26]. These cytokines could play a role in vascular remodeling associated with placentation. The cytokine IL-1 mainly affects inflammatory processes but also possesses various immune, degradative, and growth promoting properties. There are two IL-1 agonistic proteins, IL-1 $\alpha$ and IL- $1 \beta$. Both were shown to contribute to tumor angiogenesis and invasiveness, but the role of IL-1 $\beta$ is more evident in these processes [27].

Tocopherol has immunomodulatory effects, besides its antioxidant properties. Vitamin E is implicated in placental and embryonic development, whereas its deficiency affects embryo survival, and placental and fetal development. Alternative effects of Vitamin E have been recently reported as unrelated to its antioxidant capacity [28]. It induces the expression of VEGF promoter [28]. Vitamin E (15 mg/day) has been able to decrease abortion rate and to increase IL- 6 placental levels, while both treatments increased placental levels of VEGF [29]. We have shown that oral supplementation of tocopherol induces angiogenesis in placental vascular network in late pregnant ewes [10]. The hypothesis of the study is that the tocopherol's angiogenic effect following oral supplementation during late gestation in ewes is via promoting interleukins.

The objective of this study is to investigate whether tocopherol's angiogenic activity in placental network is enhanced via promoting interleukins in pregnant ewes during late gestation.

\section{Methods}

Animals

Eighteen pregnant ewes (2-6 years of age and weighing approximately $68 \mathrm{~kg}$; bred by different sires), with similar breeding dates were selected for the current study. The ewes were maintained under normal pasture conditions until the beginning of the supplementation trial. One week prior to the trial, the selected ewes were moved to the research facility and were penned by treatment groups. The ewes had access to $35 \mathrm{sq} \mathrm{ft} /$ ewe paddock lots. In addition they were fed $250 \mathrm{~g}$ of concentrate/ewe/day and free choice hay. This study was approved by institutional animal care and use committee at Washington State University (ASAF \#03922001).

\section{Treatment groups and samples collection}

The ewes were randomly assigned to three groups: 1) aT group ( $\mathrm{n}=6$ )-received $500 \mathrm{mg}$ of alpha tocopherol (aT; Nature's Bounty, Bohemia, NY 11716), 2) gT group ( $\mathrm{n}=$ 7)-received 1,000 mg of gamma tocopherol (gT; Kemin Industries Inc., Des Moines, Iowa 50317), 3) Control $(\mathrm{CON})$ group $(\mathrm{n}=5)$-received a placebo. Animals were supplemented orally, once daily, from approximately 100 to 137 days post breeding (dpb). At the end of the supplementation period $(136 \pm 1)$, all ewes were euthanized and tissue samples were collected from the gravid uterus and placentomes to evaluate a $\mathrm{T}$ and gT concentrations. Placentomal and uterine tissues were collected close to the umbilical cord for consistency. Tissue samples were snap frozen and stored at $-70^{\circ} \mathrm{C}$ until analysis. Caruncle, cotyledon and intercaruncular uterus samples were also collected and stored in RNAlater (Qiagen Inc., Valencia, CA 91355) and frozen at $-70^{\circ} \mathrm{C}$ to evaluate mRNA expression. Cotyledones were separated from caruncles by applying strong pressure.

\section{Polymerase chain reaction of selected genes of interest Total RNA extraction from tissues}

Total RNA was extracted from uterine and placentomal tissues with RNeasy Mini Kit (QIAGEN Inc. Valencia, CA, USA) according to the manufacturer's protocol. RNA concentration was measured using a NanoDrop spectrophotometer (Thermo Fisher Scientific Inc. West Palm Beach, FL, USA). Sample absorbance ratio of 260/ 280 wave-length was observed to ensure the purity of RNA and they were close to 2.00. The RNA samples were stored at $-20^{\circ} \mathrm{C}$ until complementary DNA (cDNA) preparation.

\section{Polymerase chain reaction of selected genes of interest}

The mRNA was reverse-transcribed to cDNA. The cDNA samples were prepared using the iScript cDNA Synthesis kit (Bio-Rad, Hercules, CA, USA). A 500 ๆg sample of RNA was reverse transcribed in $20 \mu \mathrm{L}$ reaction at the incubating conditions of $25^{\circ} \mathrm{C}$ for $5 \mathrm{~min}, 42^{\circ}$ $\mathrm{C}$ for $30 \mathrm{~min}$ and $85^{\circ} \mathrm{C}$ for $5 \mathrm{~min} ; 25 \eta \mathrm{g} / \mu \mathrm{L}$ RNA equivalent cDNA was obtained. Qiagen Tag PCR master 
mix (Qiagen, Valencia, CA, USA), a pre-mixed solution was used to amplify the fragment of the genes of interest. Final concentration of the primers was $0.3 \mu \mathrm{M}$. Initial denaturation was set at $94^{\circ} \mathrm{C}$ for $3 \mathrm{~min}$. Followed by 30 cycles of denaturation at $94^{\circ} \mathrm{C}$ for $1 \mathrm{~min}$, annealing at $55^{\circ} \mathrm{C}$ for $1 \mathrm{~min}$ and extension at $72^{\circ} \mathrm{C}$ was programmed. A final extension step at $72^{\circ} \mathrm{C}$ for 10 min was included in thermo-cycling conditions. Primers (Table 1) were designed either using the NCBI website or primer express version 3.0 (Applied Biosystems Inc., Carlsbad, CA, USA). Consideration was given to the set of primers (forward and reverse primers) to ensure separation of at least an intron and melting temperatures and CG content were set at optimal, or close to optimal level. Amplicon was run on a $2 \%$ agarose gel and stained with ethidium bromide for visualization to ensure a single amplicon for a set of primers (Additional file 1: Figure S1).

\section{Determination of mRNA expression using real-time PCR}

SYBR green chemistry was applied to observe relative mRNA expression. Fast SYBR green master mix $(2 \times)$ (Applied Biosystems Inc., Carlsbad, CA, USA) was used to prepare the reaction mix. The final concentration of each primer was $0.3 \mu \mathrm{M}$. A $20 \mu \mathrm{L}$ aliquot of three technical replicates were used for each sample. A $1.6 \mu \mathrm{L}$ volume of $25 \mathrm{ng} / \mu \mathrm{L}$ RNA equivalent cDNA was present in the total volume of the three triplicates. StepOne Plus instrument (Applied Biosystems Inc., Carlsbad, CA, USA) was used for the real time PCR runs. Pre-cycling stage was maintained at $95^{\circ} \mathrm{C}$ for 20 s. Forty cycle amplification was carried out with the conditions of $95^{\circ}$ $\mathrm{C}$ for $3 \mathrm{~s}$ and $60^{\circ} \mathrm{C}$ for $30 \mathrm{~s}$ (fast ramp speed conditions for the fast mixture). A continuous dissociation step was added to look for additional amplification products.

Carboxy X rhodamine ( $\mathrm{XOX}$ ) dye was set up for the passive internal reference. The baseline was automatically adjusted to obtain threshold cycles of each sample. Threshold cycles were normalized to an endogenous control, $\beta$-actin. A standard curve was obtained using 1 in 5 dilutions for each set of primer in order to check the amplification efficiency. Correlation co-efficient for the dilution curve was $\geq 0.9900$.

\section{Statistical analysis}

The RT-PCR data were subjected to ANOVA (SAS Version 9.12, Cary, NC, USA) using $2^{-\Delta \Delta C t}$ values to ascertain statistical significance of any differences in IL-1b, IL-6, IL-8, TNF $\alpha$, VEGF, KDR, and sFlt1 expression in placebo vs. tocopherol-treated groups in the placenta and uterus $[10,30]$. There were 3 ewes ( 2 in CON and 1 in aT groups) with twins. As the outcome remained the same whether or not the values from the second fetus of twins were included in the analysis, the results presented here included values from one fetus of the twins. It was hypothesized that the mean differences in mRNA expressions will be 7 fold differences in treated compared to control groups. To detect the same differences in the mean mRNA expression, with adequate statistical power $(1-\beta=0.8)$ and statistical significance $(\alpha=0.05)$, the study will need a sample size of 3 ewes per treatment group.

Table 1 Primers used for CDNA amplification of the targets by RT-PCR

\begin{tabular}{|c|c|c|c|c|}
\hline Gene & Primer & Seq $5^{\prime}$ to $3^{\prime}$ & Product length & Accession number \\
\hline \multirow[t]{2}{*}{$\mathrm{IL}-1 \mathrm{~b}$} & Forward & TCACAGGAAATGAGCCGAGAA & 150 & NM_001009465 \\
\hline & Reverse & CAGCTGCAGGGTCGGTGTAT & & \\
\hline \multirow[t]{2}{*}{ IL-6 } & Forward & ACACCACCCCAAGCAGACTACT & 200 & NM_001009392 \\
\hline & Reverse & CCCAGATTGGAAGCATCCAT & & \\
\hline \multirow[t]{2}{*}{ IL-8 } & Forward & GCCAGAAGAAACCTGACAAAAAG & 220 & NM_001009401 \\
\hline & Reverse & GCAGTGTGGCCCACTCTCA & & \\
\hline \multirow[t]{2}{*}{ VEGF } & Forward & CCTCACCAAAGCCAGCACAT & 150 & AF071015.1 \\
\hline & Reverse & CGTCTGCGGATCTTGTACAAAC & & \\
\hline \multirow[t]{2}{*}{ KDR } & Forward & GATGCTCGCCTCCCTITGA & 250 & AF233076 \\
\hline & Reverse & GATCCCCATGCCAGCAATC & & \\
\hline \multirow[t]{2}{*}{ SFlt1 } & Forward & GCCACGCCTGAAATCTACCA & 150 & AF233077 \\
\hline & Reverse & GGCGTTGAGCGGAATGTAGT & & \\
\hline \multirow[t]{2}{*}{ TNF $\alpha$} & Forward & GACCCTCCTCATCCСCTTCT & 300 & NM_001024860.1 \\
\hline & Reverse & AGCCCACCCATGTCAAGTTC & & \\
\hline \multirow[t]{2}{*}{$\beta$-actin } & Forward & CCAAGGCCAACCGTGAGA & 86 & NM_001009784.1 \\
\hline & Reverse & AGCCTGGATGGCCACGT & & \\
\hline
\end{tabular}

Ovine Interleukin (IL)-1b, IL-6, IL-8, Vascular Endothelial Growth Factor (VEGF), Kinase insert Domain Receptor (KDR), soluble Fms-Like Tyrosine kniase-1 (sFlt1), Tumor Necrosis Factor (TNF) $\alpha$ and $\beta$-actin CDNA were amplified by RT-PCR from the uterus and placenta total RNA using the above set of primers 


\section{Results}

The mRNA expressions of IL-6, IL-8, IL-1b, TNF- $\alpha$, VEGF, sFlt1 and KDR in placenta and uterus in tocopherol supplemented groups relative to $\mathrm{CON}$ (where CON group is 1), are given in Figures 1, 2 and 3. In cotyledon (Figure 1) and caruncle (Figure 2), the IL-6, IL-8, VEGF and KDR in ewes supplemented with gT were significantly higher in abundance compared to the CON group $(P<0.05)$. The IL-1b, sFlt1 mRNA abundances in cotyledon (Figure 1) and sFlt1 mRNA abundance in caruncle (Figure 2$)$ were lower $(P<0.05)$ in gT group compared to the CON groups. The supplementation of aT suppressed mRNA expression of IL-8, IL-1b, TNF- $\alpha$ and KDR in cotyledon (Figure 1), and IL-1b and TNF- $\alpha$ in caruncle (Figure 2) compared to placebo treated ewes $(P<0.05)$.

In the uterus, the IL- 6 and IL-8, VEGF and KDR mRNA expressions in ewes supplemented with gT were significantly higher in abundance, where as IL-1b and sFlt1 was significantly lower in abundance compared to the CON group (Figure 3). The IL-6, IL-8, IL-1b and KDR and TNF- $\alpha$ mRNA abundance in ewes supplemented with aT were significantly lower compared to the CON group (Figure 3).

Oral supplementation of gT increased IL-6, IL-8, KDR and VEGF mRNA expression whereas sFlt1 mRNA expression was suppressed in cotyledon (Figure 1), caruncle (Figure 2) and uterus (Figure 3) compared to aT treated ewes $(P<0.05)$. The mRNA abundances of both TNF- $\alpha$ and IL-1b was suppressed in uterus, caruncle and cotyledon but TNF- $\alpha$ was different between gT and aT treatment groups whereas IL-1b was similar between treatment groups $(P>0.1)$.

\section{Discussion}

In this study we observed that supplementation of gT to pregnant ewes during late gestation increased IL-6, IL-8, KDR and VEGF mRNA abundances in uterus, caruncle and cotyledon whereas the mRNA expression of IL-1b, sFlt1 was suppressed compared to placebo treated ewes. In contrast, supplementation of aT suppressed mRNA expression of IL-1b, IL- 6 and KDR in both cotyledon and caruncle, and IL- 8 in cotyledon, compared to placebo treated ewes $(P<0.05)$.

In our previous study, we showed that the tocopherol concentrations of uterus and placentome increased following oral supplementation of tocopherol during late gestation in pregnant ewes [10]. IL-8 signaling has been shown to promote the transactivation of the epidermal growth factor receptor in vascular endothelial cells $[31,32]$, promoting downstream activation of MAPK signaling. In addition, IL-8 signaling has been shown to induce the phosphorylation of the KDR, (VEGFR-2) in endothelial cells, regulating the permeability of the

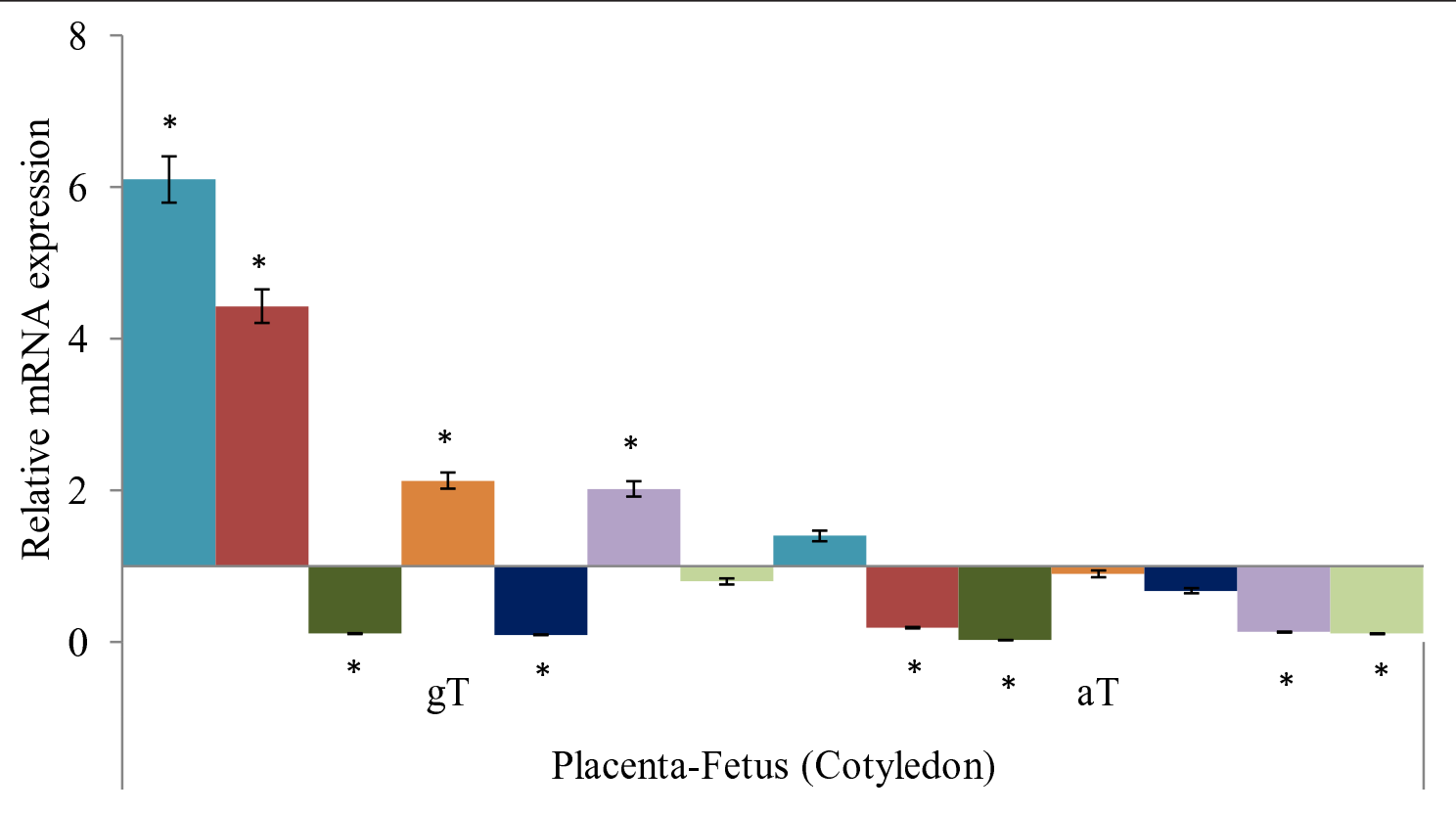

IL-6 IL-8 a IL-1b $\square$ VEGF $\square$ SFlt1 $\square$ KDR $\square$ TNFa

Figure 1 Relative mRNA of target genes expressed in cotyledon of late pregnant ewes following oral supplementation of alpha tocopherol, gamma tocopherol or placebo. a. Interleukin(IL)-6, IL-8, IL-1b, Vascular Endothelial Growth Factor (VEGF), Kinase insert Domain Receptor (KDR), soluble Fms-Like Tyrosine kniase-1 (sFlt1) and Tumor Necrosis Factor (TNF) a mRNA expressions in cotyledon following gamma tocopherol (gT) or alpha tocopherol (aT) oral supplementation ( $\times$ expression relative to control $=1 ;{ }^{*} P<0.05$ ). 


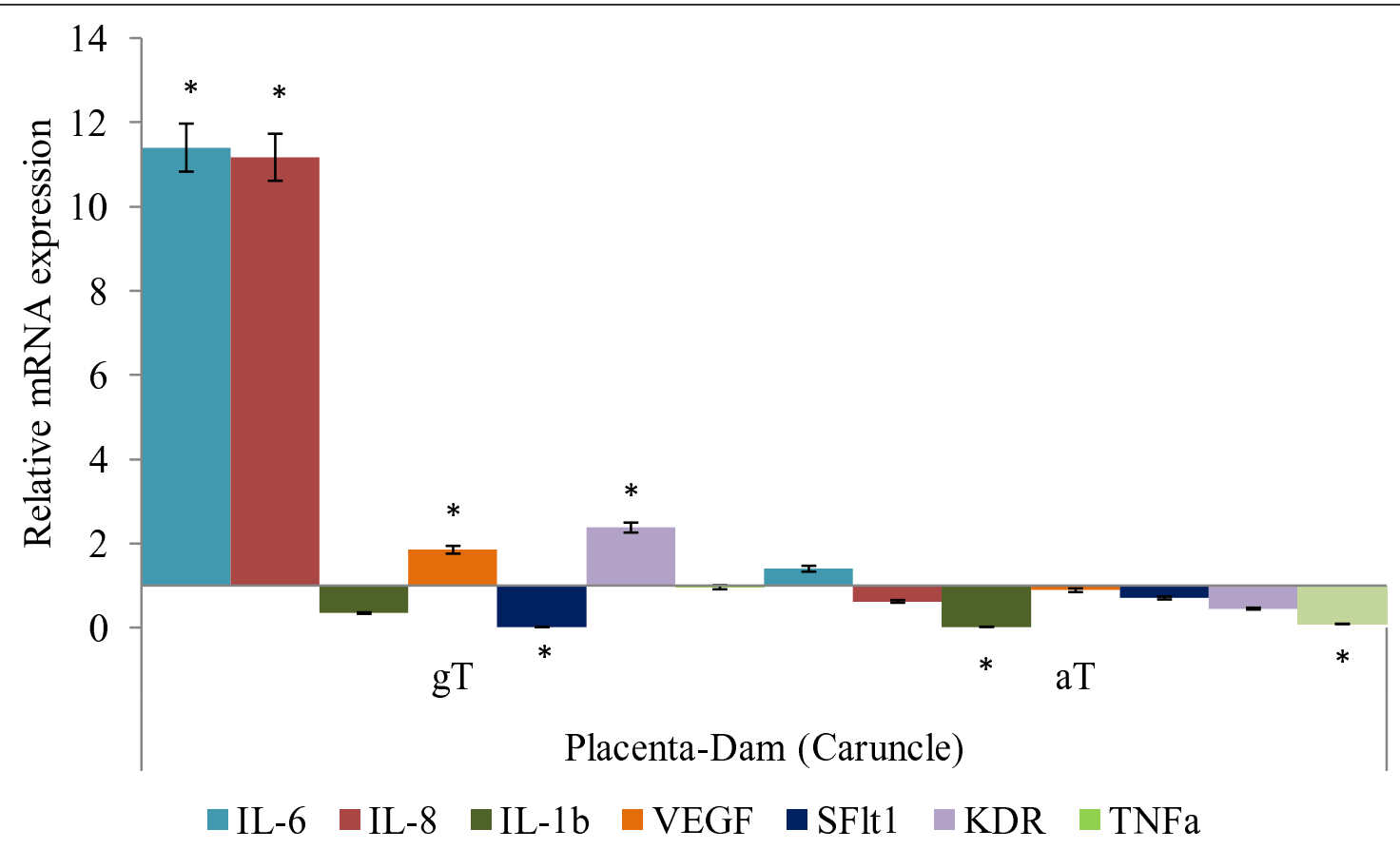

Figure 2 Relative mRNA of target genes expressed in caruncle of late pregnant ewes following oral supplementation of alpha tocopherol, gamma tocopherol or placebo. a. Interleukin(IL)-6, IL-8, IL-1b, Vascular Endothelial Growth Factor (VEGF), Kinase insert Domain Receptor (KDR), soluble Fms-Like Tyrosine kniase-1 (sFlt1) and Tumor Necrosis Factor (TNF) a mRNA expressions in caruncle following gamma tocopherol $(\mathrm{gT})$ or alpha tocopherol (aT) oral supplementation ( $\times$ expression relative to control $=1 ;{ }^{*} P<0.05$ ).

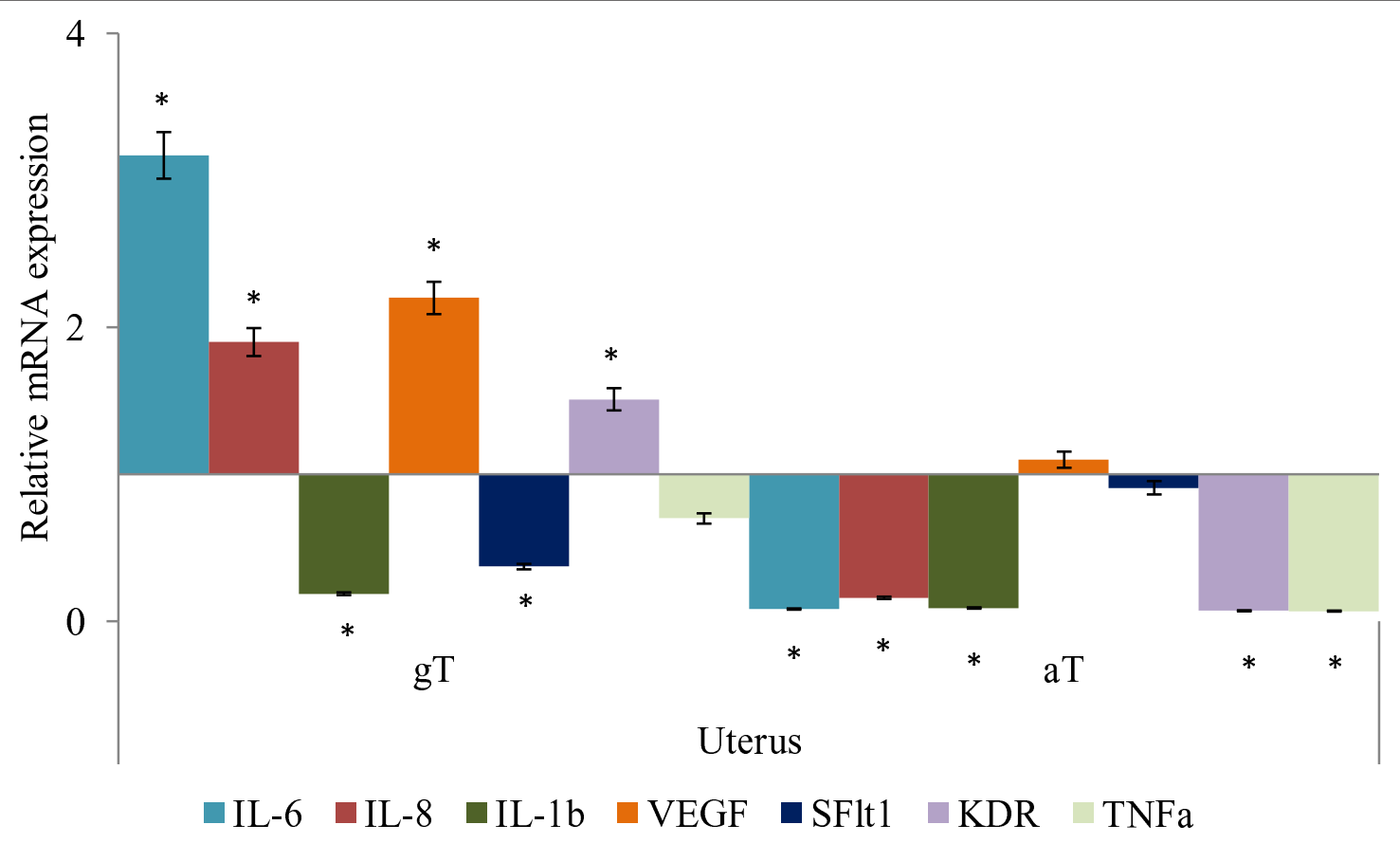

Figure 3 Relative mRNA of target genes expressed in uterus of late pregnant ewes following oral supplementation of alpha tocopherol, gamma tocopherol or placebo. Interleukin(IL)-6, IL-8, IL-1b, Vascular Endothelial Growth Factor (VEGF), Kinase insert Domain Receptor (KDR), soluble Fms-Like Tyrosine kniase-1 (sFlt1) and Tumor Necrosis Factor (TNF) $\alpha$ mRNA expressions in uterus following gamma or alpha tocopherol oral supplementation ( $\times$ expression relative to control $=1$; ${ }^{*} P<0.05$ ). 
endothelial barrier [33]. Protein tyrosine kinases are a further downstream target of IL-8 signaling responses in endothelial cells [31]. In our previous study, we demonstrated increased fractal dimension and lowered lacunarity, signs for improved angiogenesis, in placental vascular network following gT supplementation compared to aT supplemented and control ewes during late gestation [10]. In this study, we demonstrated increased IL-8, KDR and VEGF mRNA abundances in gT supplemented ewes. The stimulatory effect of IL-8 might plausibly be regulated by increased VEGF mRNA expression, which is enhanced via both VEGFR1 (low sFlt1 mRNA abundance) and VEGFR2 (high KDR mRNA abundance).

Fan et al. (2008) showed that interleukin (IL)-6 increased endothelial progenitor cell proliferation, migration and in vitro angiogenic-like tubulogenesis [22]. It appears that lower IL-6 levels may induce a deregulation leading to an exacerbated inflammation, a poor angiogenesis and fetal death by ischemia [29]. However, it should be noted that the underlying angiogenic mechanism is that IL- 6 upregulates KDR. IL-6 triggers VEGF-induced angiogenic activity through increasing VEGF release, up-regulates KDR expression and phosphorylation through activating ERK1/2 signaling, and stimulates MMP-9 overexpression [34,35]. It is evident, in this study, that ewes supplemented with gT had increased IL-6, VEGF and KDR causing enhanced angiogenesis in the placental vascular network in that group.

Numerous studies demonstrated a role for IL-6 in increased blood pressure. For example, plasma levels of IL-6 are strongly associated with hypertension in humans and can be reduced by administration of Ang II receptor antagonists [36-38]. Animal studies showed that infusion of IL-6 induces hypertension in pregnant rats $[39,40]$. Trophoblast cells are capable of responding to IL-6 [41-43]. Trophoblast cells have a JAK/STAT-signaling pathway that functions downstream of IL-6R activation. JAK/STAT signaling, downstream of IFN- $\gamma$ stimulation, is responsible for increased sFlt-1 production by human corneal fibroblasts [44]. The authors speculated that the IL- 6 stimulates sFlt- 1 and sEng production by trophoblast cells in an autocrine manner by JAK-STAT signaling, and that increased IL- 6 contributes to antibody-mediated hypertension in women with PE via IL-6-induced stimulation of sFlt-1 production by trophoblasts [44]. Interestingly in this study, sFlt-1 mRNA expression is suppressed in tocopherol treated groups plausibly explaining that ischemic necrosis is prevented by such treatment thus favoring angiogenesis.

IL-1b is a potent immunoregulatory and proinflammatory cytokine secreted by a variety of activated immune cells. Several studies provide evidence that angiogenesis and VEGF is IL-1 dependent [45-48] and the major transcriptional activator of the VEGF gene is HIF (Hypoxia Inducible Factor) [49]. IL-1b induced a pattern of gene expression to favor vascular permeability involving the HIF-VEGF axis [50]. Activation of the ERK1/2 pathway by IL-1b may result in the accumulation of HIF-1a protein, which initiates VEGF secretion in normal human cytotrophoblast cells. In the previous study, we observed that VEGF, HIF-1a and HIF-2a mRNA expressions in caruncle and uterus were greater in ewes supplemented with gT compared to the ewes in the CON group which is coincided with improved angiogenesis in the placental vascular network in gT group [10]. In the present study, IL-1b mRNA abundance was suppressed in $\mathrm{gT}$ treated ewes compared to ewes in the CON group. It is plausible that the IL-1b mRNA abundance is lower during late gestation. Studies on immunohistochemical localization of IL-1a and IL-1b in normal human placenta showed that both IL-1a and IL$1 \mathrm{~b}$ forms are localized to villous syncytiotrophoblast and to extravillous trophoblast [51] and there is a gradual decrease of IL-1 reactivity with increasing gestational age. Also, IL-1a contributes to angiogenesis in hypoxia, when IL-1b secretion is reduced to suboptimal levels [51]. In addition, Molvarec et al., (2011) did not find association between serum levels of leptin and proinflammatory cytokines in preeclampsia, which might be explained-at least partly-by the fact that the latter (especially TNF- $\alpha$ and IL-1 $\beta$ ) have a very short-half life in the maternal circulation [52]. In dogs, the expression was absent in uterus during diestrus (10-12 days post ovulation), and preimplantation (10-12 dpb) and placentation sites (day 20-35 dpb) [53].

The aT exerts an inhibitory effect on the release of the proinflammatory cytokine, IL-1b, via inhibition of the 5lipoxygenase pathway [54] and aT supplementation significantly lowered levels of $\mathrm{C}$-reactive protein and interleukin-6 [55]. Also, aT inhibits of IL-8 synthesis from endothelial cells [56]. It is evident that findings from these studies showed that supplementation of aT suppressed the expression of interleukins. In this study, the supplementation of aT suppressed mRNA expression of IL-1b, IL- 6 and KDR in placentome, and IL- 8 in caruncle compared to placebo treated ewes.

It should be noted that the protein expressions work was not performed in this study. However, protein expressions of proinflammatory cytokines and angiogenic markers in sheep placental tissues were reported in mid and late gestation $[57,58]$.

\section{Conclusions}

Gamma tocopherol supplementation increased IL-6, IL8 and KDR mRNA expression, and suppressed sFlt1 mRNA expression in uterus, caruncle and cotyledon 
during late gestation. In addition, the VEGF mRNA expression in uterus, caruncle and cotyledon is also increased following supplementation during late gestation. The increase in VEGF mRNA abundance is enhanced via both VEGFR1 (low sFlt1) and VEGFR2 (high KDR) mRNA abundances. Taken findings from this study together, it is conceivable that the angiogenic effect of gamma tocopherol in placental vascular network is exerted via an alternate path by enhancing IL-6 and IL-8 mRNA.

\section{Additional material}

Additional file 1: Figure S1. Photograph of the ethidium bromidestained electrophoresis gel, with amplicons of the expected sizes.

\section{Acknowledgements}

This study was funded by College of Veterinary Medicine, Washington State University, Pullman WA 99164.

\section{Authors' contributions}

RK did the work of acquisition of funding, conception, design and collection of data; data analysis and interpretation, drafting of the manuscript, tables and figures. VK contributed to the design and conception, PCR analysis, collection of data and drafted the manuscript. GH and AT helped with concepts and drafting the manuscript. All authors have read and approved the final manuscript.

\section{Competing interests}

The authors declare that they have no competing interests.

Received: 20 October 2011 Accepted: 23 January 2012

Published: 23 January 2012

\section{References}

1. Folkman J, Klagsbrun M: Angiogenic factors. Science 1987, 235:442-447.

2. Reynolds LP, Borowicz PP, Vonnahme KA, Johnson ML, Grazul-Bilska AT, Redmer DA, Caton JS: Placental angiogenesis in sheep models of compromised pregnancy. J Physiol 2005, 15:43-58.

3. Borowicz PP, Arnold DR, Johnson ML, Grazul-Bilska AT, Redmer DA, Reynolds LP: Placental growth throughout the last two thirds of pregnancy in sheep: vascular development and angiogenic factor expression. Biol Reprod 2007, 76:259-267.

4. Sherer DM, Abulafia O: Angiogenesis during implantation, and placental and early embryonic development. Placenta 2001, 22:1-13.

5. Zygmunt M, Herr F, Munstedt K, Lang U, Liang OD: Angiogenesis and vasculogenesis in pregnancy. Eur J Obstet Gynecol Reprod Biol 2003, 110: S10-S18.

6. Folkman J: Angiogenesis in cancer, vascular, rheumatoid and other disease. Nat Med 1995, 1:27-31.

7. Gerhardt H, Golding M, Fruttiger M, Ruhrberg C, Lundkvist A, Abramsson A, Jeltsch M, Mitchell C, Alitalo K, Shima D, Betsholtz C: VEGF guides angiogenic sprouting utilizing endothelial tip cell filopodia. J Cell Biol 2003, 161:1163-1177.

8. Cheung CY, Singh M, Ebaugh MJ, Brace RA: Vascular endothelial growth factor gene expression in ovine placenta and fetal membranes. Am J Obstet Gynecol 1995, 173:753-759.

9. Park JE, Chen HH, Winer J, Houck KA, Ferrara N: Placenta growth factor. Potentiation of vascular endothelial growth factor bioactivity, in vitro and in vivo, and high affinity binding to Flt-1 but not to Flk-1/KDR. J Biol Chem 1994, 269:25646-25654

10. Kasimanickam RK, Kasimanickam VR, Rodriguez JS, Pelzer KD, Sponenberg PD, Thatcher CD: Tocopherol induced angiogenesis in placental vascular network in late pregnant ewes. Reprod Biol Endocrinol 2010, 8:86.

11. de Vrijer B, Davidsen ML, Wilkening RB, Anthony RV, Regnault TR: Altered placental and fetal expression of IGFs and IGF-binding proteins associated with intrauterine growth restriction in fetal sheep during early and mid-pregnancy. Pediatr Res 2006, 60:507-512.

12. Plouet J, Moukadiri $\mathrm{H}$ : Characterization of the receptor to vasculotropin on bovine adrenal cortex-derived capillary endothelial cells. J Biol Chem 1990, 265:22071-22074.

13. Wolff B, Burns AR, Middleton J, Rot A: Endothelial cell "memory" of inflammatory stimulation: human venular endothelial cells store interleukin 8 in Weibel-Palade bodies. J Exp Med 1998, 188:1757-1762.

14. Utgaard JO, Jahnsen FL, Bakka A, Brandtzaeg P, Haraldsen G: Rapid secretion of prestored interleukin 8 from Weibel-Palade bodies of microvascular endothelial cells. J Exp Med 1998, 188:1751-1756.

15. Salcedo R, Resau JH, Halverson D, Hudson EA, Dambach M, Powell D, Wasserman K, Oppenheim JJ: Differential expression and responsiveness of chemokine receptors (CXCR1-3) by human microvascular endothelial cells and umbilical vein endothelial cells. FASEB J 2000, 14:2055-2064.

16. Koch AE, Polverini PJ, Kunkel SL, Harlow LA, DiPietro LA, Elner VM, Elner SG, Strieter RM: Interleukin-8 as a macrophage-derived mediator of angiogenesis. Science 1992, 258:1798-1801.

17. Strieter RM, Kunkel SL, Elner VM, Martonyi CL, Koch AE, Polverini PJ, Elner SG: Interleukin-8. A corneal factor that induces neovascularization. Am J Pathol 1992, 141:1279-1284.

18. Li A, Dubey S, Varney ML, Dave BJ, Singh RK: IL-8 directly enhanced endothelial cell survival, proliferation, and matrix metalloproteinases production and regulated angiogenesis. J Immunol 2003, 170:3369-3376.

19. Kamimura D, Ishihara K, Hirano T: IL-6 signal transduction and its physiological roles: the signal orchestration model. Rev Physiol Biochem Pharmacol 2003, 149:1-38.

20. Taga T, Kishimoto T: Gp130 and the interleukin-6 family of cytokines. Annu Rev Immuno 1997, 15:797-819.

21. Fan $Y$, Ye J, Shen F, Zhu Y, Yeghiazarians Y, Zhu W, Chen Y, Lawton MT, Young WL, Yang GY: Interleukin-6 stimulates circulating blood-derived endothelial progenitor cell angiogenesis in vitro. J Cereb Blood Flow Metab 2008, 28:90-98.

22. Jauniaux E, Beatrice Gulbis B, Schandene L, Collette J, Hustin J: Distribution of interleukin- 6 in maternal and embryonic tissues during the first trimester. Mol Hum Reprod 1996, 2:239-243.

23. Fee D, Grzybicki D, Dobbs M, Ihyer S, Clotfelter J, Macvilay S, Hart MN, Sandor M, Fabry Z: Interleukin 6 promotes vasculogenesis of murine brain microvessel endothelial cells. Cytokine 2000, 12:655-665.

24. Hernandez-Rodriguez J, Segarra M, Vilardell C, Sanchez M, GarciaMartinez A, Esteban MJ, Grau JM, Urbano-Marquez A, Colomer D, Kleinman HK, Cid MC: Elevated production of interleukin- 6 is associated with a lower incidence of disease-related ischemic events in patients with giant-cell arteritis: angiogenic activity of interleukin- 6 as a potential protective mechanism. Circulation 2003, 107:2428-2434.

25. Banerjee K, Biswas PS, Kim B, Lee S, Rouse BT: CXCR2\%mice show enhanced susceptibility to herpetic stromal keratitis: a role for IL-6induced neovascularization. J Immunol 2004, 172:1237-1245.

26. Huang SP, Wu MS, Shun CT, Wang HP, Lin MT, Kuo ML, Lin JT: Interleukin-6 increases vascular endothelial growth factor and angiogenesis in gastric carcinoma. J Biomed Sci 2004, 11:517-527.

27. Voronov E, Shouval DS, Krelin Y, Cagnano E, Benharroch D, Iwakura Y, Dinarello CA, Apte RN: IL-1 is required for tumor invasiveness and angiogenesis. Proc Natl Acad Sci USA 2003, 100:2645-2650.

28. Zhang B, Tanaka J, Yang L, Yang L, Sakanaka M, Hata R, Maeda N, Mitsuda N: Protective effect of vitamin E against focal brain ischemia and neuronal death through induction of target genes of hypoxiainducible factor-1. Neuroscience 2004, 126:433-440.

29. Junovich G, Dubinsky V, Gentile T, Sarto A, Pasqualini S, Gutiérrez G: Comparative immunological effect of anticoagulant and antioxidant therapy in the prevention of abortion in mice. Am J Reprod Immunol 2011, 65:104-109.

30. Livak KJ, Schmittgen TD: Analysis of relative gene expression data using real-time quantitative PCR and the 2(-Delta Delta $C(T))$ method. Methods 2001, 25:402-408.

31. Waugh JJD, Wilson C: The interleukin-8 pathway in cancer. Clin Cancer Res 2008, 14:6735-6741. 
32. Schraufstatter IU, Trieu K, Zhao M, Rose DM, Terkeltaub RA, Burger M: IL-8 mediated cell migration in endothelial cells depends on cathepsin B activity and transactivation of the epidermal growth factor receptor. J Immunol 2003, 171:6714-6722.

33. Petreaca ML, Yao M, Lui Y, Defea K, Martins-Green M: Transactivation of vascular endothelial growth factor receptor-2 by interleukin-8 (IL-8/ CXCL8) is required for IL-8/CXCL8-induced endothelial permeability. Mol Biol Cell 2007, 18:5014-5023.

34. Yao JS, Zhai W, Fan Y, Lawton MT, Barbaro NM, Young WL, Yang GY: Interleukin-6 upregulates expression of KDR and stimulates proliferation of human cerebrovascular smooth muscle cells. J Cereb Blood Flow Metab 2007, 27:510-520.

35. Yao JS, Zhai W, Young WL, Yang GY: Interleukin-6 triggers human cerebral endothelial cells proliferation and migration: the role for KDR and MMP9. Biochem Biophys Res Commun 2006, 342:1396-1404.

36. Fliser D, Buchholz K, Haller H: Antiinflammatory effects of angiotensin II subtype 1 receptor blockade in hypertensive patients with microinflammation. Circulation 2004, 110:1103-1107.

37. Manabe S, Okura T, Watanabe S, Fukuoka T, Higaki J: Effects of angiotensin II receptor blockade with valsartan on pro-inflammatory cytokines in patients with essential hypertension. J Cardiovasc Pharmacol 2005, 46:735-739.

38. Vázquez-Oliva G, Fernández-Real JM, Zamora A, Vilaseca M, Badimón L: Lowering of blood pressure leads to decreased circulating interleukin-6 in hypertensive subjects. J Hum Hypertens 2005, 19:457-462.

39. Gadonski G, LaMarca BB, Sullivan E, Bennett W, Chandler D, Granger JP: Hypertension produced by reductions in uterine perfusion in the pregnant rat: role of interleukin 6. Hypertension 2006, 48:711-716.

40. Orshal JM, Khalil RA: Interleukin-6 impairs endothelium-dependent NOcGMP-mediated relaxation and enhances contraction in systemic vessels of pregnant rats. Am J Physiol Regul Integr Comp Physiol 2004, 286: R1013-R1023.

41. Agarwal R, Loganath A, Roy AC, Wong YC, Lindoff C, Ng SC: Increased expression of interleukin 6 in term compared to the first trimester human placental villi. Horm Metab Res 2000, 32:164-168.

42. Bowen RS, Gu Y, Zhang Y, Lewis DF, Wang Y: Hypoxia promotes interleukin- 6 and -8 but reduces interleukin- 10 production by placental trophoblast cells from preeclamptic pregnancies. J Soc Gynecol Investig 2005, 12:428-432.

43. Jones HN, Jansson T, Powell TL: IL-6 stimulates system a amino acid transporter activity in trophoblast cells through STAT3 and increased expression of SNAT2. Am J Physiol Cell Physiol 2009, 297:C1228-C1235.

44. Zhou CC, Irani RA, Dai Y, Blackwell SC, Hicks MJ, Ramin SM, Kellems RE, Xia Y: Autoantibody-mediated IL-6-dependent endothelin-1 elevation underlies pathogenesis in a mouse model of preeclampsia. J Immunol 2011, 186:6024-6034

45. Elaraj DM, Weinreich DM, Varghese S, Puhlmann M, Hewitt SM, Carroll NM, Feldman ED, Turner EM, Alexander HR: The role of interleukin 1 in growth and metastasis of human cancer xenografts. Clinic Cancer Res 2006, 12:1088-1096.

46. Voronov E, Shouval DS, Krelin Y, Cagnano E, Benharroch D, Iwakura Y, Dinarello CA, Apte RN: IL-1 is required for tumor invasiveness and angiogenesis. PNAS USA 2003, 100:2645-2650.

47. Carmi Y, Voronov E, Dotan S, Lahat N, Rahat MA, Fogel M, Huszar M, White MR, Dinarello CA, Apte RN: The role of macrophage-derived IL-1 in induction and maintenance of angiogenesis. J Immunol 2009 183:4705-4714

48. Coxon A, Bolon B, Estrada J, Kaufman S, Scully S, Rattan A, Duryea D, Hu YL, Rex K, Pacheco E, Van G, Zack D, Feige U: Inhibition of interleukin-1 but not tumor necrosis factor suppresses neovascularization in rat models of corneal angiogenesis and adjuvant arthritis. Arthrit Rheumat 2002, 46:2604-2612.

49. Hellwig-Burgel T, Rutkowski K, Metzen E, Fandrey J, Jelkmann W: Interleukin-1beta and tumor necrosis factor-alpha stimulate DNA binding of hypoxia-inducible factor-1. Blood 1999, 94:1561-1567.

50. Argaw AT, Zhang Y, Snyder BJ, Zhao ML, Kopp N, Lee SC, Raine CS, Brosnan CF, John GR: IL-1 beta regulates blood-brain barrier permeability via reactivation of the hypoxia-angiogenesis program. J Immunol 2006, 177:5574-5584.
51. Paulesu L, King A, Loke YW, Cintorino M, Bellizzi E, Boraschi D: Immunohistochemical localization of IL-1 alpha and IL-1 beta in normal human placenta. Lymphokine Cytokine Res 1991, 10:443-448.

52. Molvarec A, Szarka A, Walentin W, Beko G, Karadi I, Prohaszka Z, Rigo J: Serum leptin levels in relation to circulating cytokines, chemokines, adhesion molecules and angiogenic factors in normal pregnancy and preeclampsia. Reprod Biol Endocrinol 2011, 9:124.

53. Beceriklisoy HB, Schäfer-Somi S, Kücükaslan I, Agaoglu R, Gültiken N, Ay SS, Kaya D, Aslan S: Cytokines, growth factors and prostaglandin synthesis in the uterus of pregnant and non-pregnant bitches: the features of placental sites. Reprod Domest Anim 2009, 44(Suppl 2):115-119.

54. Devaraj S, Jialal I: Alpha-tocopherol decreases interleukin-1 beta release from activated human monocytes by inhibition of 5-lipoxygenase. Arterioscler Thromb Vasc Biol 1999, 19:1125-1133.

55. Devaraj S, Jialal I: Alpha tocopherol supplementation decreases serum Creactive protein and monocyte interleukin- 6 levels in normal volunteers and type 2 diabetic patients. FRBM 2000, 29:790-792.

56. Nobata $Y$, Urakaze $M$, Temaru $R$, Sato A, Nakamura N, Yamazaki $K$ Kishida M, Takata M, Kobayashi M: alpha-Tocopherol Inhibits IL-8 synthesis induced by thrombin and high glucose in endothelial cells. Horm Metab Res 2002, 34:49-54.

57. Zhu MJ, Du M, Nathanielsz PW, Ford SP: Maternal obesity up-regulates inflammatory signaling pathways and enhances cytokine expression in the mid-gestation sheep placenta. Placenta 2010, 31:387-391.

58. Ma Y, Zhu MJ, Zhang L, Hein SM, Nathanielsz PW, Ford SP: Maternal obesity and overnutrition alter fetal growth rate and cotyledonary vascularity and angiogenic factor expression in the ewe. Am J Physiol Regul Integr Comp Physiol 2010, 299:R249-R258.

doi:10.1186/1477-7827-10-4

Cite this article as: Kasimanickam et al:: Effect of tocopherol supplementation during last trimester of pregnancy on mRNA abundances of interleukins and angiogenesis in ovine placenta and uterus. Reproductive Biology and Endocrinology 2012 10:4.

\section{Submit your next manuscript to BioMed Central and take full advantage of:}

- Convenient online submission

- Thorough peer review

- No space constraints or color figure charges

- Immediate publication on acceptance

- Inclusion in PubMed, CAS, Scopus and Google Scholar

- Research which is freely available for redistribution

Submit your manuscript at www.biomedcentral.com/submit
C) Biomed Central 